\title{
RISK CONTROL STRATEGIES FOR RED CHILI SEED PRODUCTION
}

\author{
Intan Pujiarti, Djoko Koestiono, Anisa Aprilia*, and Riska Ayu Febriana \\ Department of Agricultural Socio-Economics, Faculty of Agriculture, Brawijaya University, Malang, \\ Indonesia \\ Email: anisa.asa@ub.ac.id
}

Submitted 04 January 2020; Accepted 10 August 2020

\begin{abstract}
ABSTRAK
Penelitian ini bertujuan mengidentifikasi komponen risiko, menentukan prioritas komponen risiko dan merumuskan strategi untuk pengendalian komponen risiko prioritas pada setiap tahapan proses produksi benih cabai merah. Analisis dalam penelitian menggunakan metode Fuzzy FMEA (Failure Mode Effects Analysis) dan AHP (Analytical Hierarchy Process). Hasil penelitian mengenai risiko produksi terdapat 15 komponen risiko dari 6 variabel. Komponen risiko prioritas tertinggi masingmasing proses produksi benih cabai merah yaitu kegagalan dalam persemaian, bibit mati setelah tanam, kondisi cuaca yang berubah-ubah, busuk buah cabai, kerusakan mesin pelepas biji dan kadar air benih cabai tidak sesuai standar. Hasil perhitungan AHP diperoleh bobot nilai tertinggi pada kriteria yaitu pemeliharaan. Alternatif strategi pengendalian yang memiliki bobot nilai tertinggi yaitu menjaga dan merawat lingkungan produksi.
\end{abstract}

Kata kunci: AHP, benih cabai merah, FFMEA, risiko produksi

\begin{abstract}
The purposes of this study were to identify risk components, determine the priority of risk components and formulate a strategy for controlling priority risk components at each stage of the red pepper seed production process. Fuzzy FMEA (Failure Mode Effects Analysis) and AHP (Analytical Hierarchy Process) were used in this study. The findings of the study showed that production risk has 15 risk components from 6 variables. The highest risk components for each of the red chilli seed production processes, namely, failure in the nursery, seedlings die after planting, changing weather conditions, rotten chilli, damage to the seed release machine and chilli seed moisture content are not according to the standard. AHP calculation results obtained the highest value weighting on the criteria, namely maintenance. An alternative control strategy that has the highest weighting value was caring and maintaining the production environment.
\end{abstract}

Keywords:_AHP, FFMEA, production risk, red chili seeds

\section{INTRODUCTION}

Production in agriculture is most vulnerable to risks. Over the years, there have been a wide variety of risks faced. The factors that cause risk are dependence on natural conditions such as rainfall, temperature changes, and pest attacks (Singla and Sagar, 2012). The same thing also stated by Iturrioz (2009), there will be many risks in agricultural production, one of which is the risk of production due to uncertainty about the level of production attained by producers in production activities. According to some researchers, production risk is a risk related to production losses. In general, climate, weather, and pests attack and diseases are the causes of the risk of crop production. The risk of production in agriculture tends to increase, this is due to climate change that causes extreme weather events, where climate change tends to increase the frequency of 
pests attack and diseases in plants. One of the agricultural products that cannot avoid the risk is the red chili seeds production.

Based on the research, quality seeds are one of the main factors of success in increasing cultivation business. The use of superior quality seeds will result in maximum production according to the target. It is necessary to consider risk management as a series of techniques that can be used to avoid or minimize losses and take advantage of opportunities that arise. Therefore, risk management is necessary for red chili seedlings.

Generally, the process of producing red chili seeds by companies is done in long stages, starting from the cultivation process, processing the seeds to the storage stage, these processes can create risk opportunities at each stage. The emergence of risks in the red chili seed production process can affect the yield of red chili seed production in each period, namely experiencing fluctuations in production. Meanwhile, the demand for chili seeds has increased, which means that companies lose opportunities and chances to meet consumer needs every year. The yield of red chili seeds production that cannot meet consumer demand is caused by risks that occur in the production process.

Various attempts have been made by the company to reduce production risk. One of the efforts made is that the process of cultivating red chilies using a screen house that aims to reduce pests attack and diseases caused by climate change and to supervise each stage of the production process. However, the efforts that have been made have not been able to produce maximum production, and thereby the result of production achieved have not met the overall consumer demand. Therefore, it is important to conduct this research to analyze the production risks faced by PT.TAP, because if it continues to happen in each process it will cause losses to the company.

This study was conducted by focusing on the measurement and identification of risk components that can occur at each stage of the production process. The indicator of the risk level is based on the level of seriousness of the effect or impact caused by a failure in a process, the possibility of failure in the production process, and the level of ability to control failure in each production process. This study will perform statistical analysis based on linguistic and fuzzy numbers and weighting of the pairwise comparison matrix. The weight value obtained is the result of the analysis used to analyze the priority of risks and controls that will be carried out.

The objective of this study is to identify the risk components contained in the red chili seed production process, determine the priority of risk components in the red chili seed production process, and formulate strategies to control the priority of risk components at each stage of the red chili seed production process.

\section{RESEARCH METHODS}

This study was conducted at a private seed company located in Central Java. The respondents were 3 people who are members of the FMEA team. According to Wang et al. (2009), team members are determined by differences in interests in knowledge, skills, and competencies. The team members in this study need to be weighted to show the differences in assessing the Fuzzy FMEA, the three members of the team are given relative weights $40 \%, 30 \%$, and $30 \%$. This study used a quantitative approach to identify and analyze the risk components of red chili seed production and to formulate control strategies. The quantitative approach is an approach to test the theories by examining the significance of the variables using research instruments. The data was measured using statistical analysis (Creswell, 2010). Data collection is obtained through interviews with companies related to the production process, documentation of the object under study, and activities in the company.

Fuzzy FMEA is an analysis tool used to identify possible risks in a process. Fuzzy FMEA was first used in 1949 by the 
American army to determine reliability and safety during the design and production process in the aeronautics sector. Experiencing developments in the application of FMEA which is used as a standard of risk measurement in several manufacturing companies in the automotive and electronics sectors, the aerospace industry, the food industry, the energy, medical, and pharmaceutical sectors (Rabbi, 2018). In 1950 and 1960, the use of Fuzzy FMEA began to be developed by Grumman Aircraft Corporation in the Navy aircraft control system (Sharma and Sharma, 2010). The current use of the FMEA method is to find risks and prioritize potential risks that will occur using the calculation of Fuzzy RPN (risk priority number).

To answer the research objectives in identifying risk components, this study used the Fuzzy Failure Mode Effects Analysis (Fuzzy FMEA) method and the analysis tool is the Analytical Hierarchy Process (AHP). The risk analysis method is carried out using Fuzzy FMEA which contains three criteria, namely the impact caused or Severity (S), the probability of occurrence or Occurrence $(\mathrm{O})$, and detection of control or Detecting (D). The analysis method using Fuzzy FMEA will produce a risk value or Fuzzy Risk Priority Number (FRPN) which is the output of the risk value of each factor selected based on weighting by the team (Risqiyah and Santoso, 2015). The value obtained based on the criteria of severity shows the magnitude of the impact or effect that may occur due to failure. The value based on occurrence shows the possible causes of the risk that may occur and the form of failure during the product usage period, while the detection value shows the measurement results of the ability to control the failure occurs. Meanwhile, data processing using the AHP method is conducted with the initial stage, which is identifying criteria that consistent with the risk indicators. Furthermore, identifying alternatives strategies according to the risks. The highest value generated can be considered in the production risk control strategy. Supported by the statement of Atanasova et al. (2014), the AHP method is used to determine the relationship between

Table 1. The Rankings of Severity of Effect

\begin{tabular}{|c|c|c|}
\hline Rating & Effect & Severity of Effects \\
\hline 10 & $\begin{array}{l}\text { Hazardous without } \\
\text { Warning }\end{array}$ & $\begin{array}{l}\text { The effect caused is very high (hazardous) with failure } \\
\text { that occurs affect the safety and without warning }\end{array}$ \\
\hline 9 & $\begin{array}{l}\text { Hazardous with } \\
\text { Warning }\end{array}$ & $\begin{array}{l}\text { The effect caused is very high (hazardous) with failure } \\
\text { that occurs affect the safety but with warning }\end{array}$ \\
\hline 8 & Very High & $\begin{array}{l}\text { The system was unable to start and failure occurs that } \\
\text { caused damage but it does not endanger the safety (non- } \\
\text { hazardous) }\end{array}$ \\
\hline 7 & High & The system was unable to start and device failure occurred \\
\hline 6 & Moderate & $\begin{array}{l}\text { The system was unable to start and minor damage } \\
\text { occurred to the device }\end{array}$ \\
\hline 5 & Low & $\begin{array}{l}\text { The system was unable to start but there was no damage to } \\
\text { the device }\end{array}$ \\
\hline 4 & Very Low & $\begin{array}{l}\text { The system can run and experiencing a significant } \\
\text { decrease in performance as a result of failure }\end{array}$ \\
\hline 3 & Minor & $\begin{array}{l}\text { The system can run and there is some decrease in } \\
\text { performance as a result of failure }\end{array}$ \\
\hline 2 & Very Minor & The system can run with minimal failures \\
\hline 1 & None & There is no effect from the failure \\
\hline
\end{tabular}

Source: Wang et al. (2009) 
Table 2. The Rankings of Probability of occurrence

\begin{tabular}{cll}
\hline Rating & \multicolumn{1}{c}{ Probability of Occurrence } & \multicolumn{1}{c}{ Probability of Error } \\
\hline 10 & Very High $(\mathrm{VH}):$ there is no prevention so the & $>1$ failure on 2 occasions \\
9 & risk of failure is almost cannot be avoided & 1 failure on 3 occasions \\
8 & High $(\mathrm{H}):$ prevention is less effective resulting & 1 failure on 8 occasions \\
7 & in repeated failure & 1 failure on 20 occasions \\
6 & & 1 failure on 80 occasions \\
5 & Moderate $(\mathrm{M}):$ there is prevention and & 1 failure on 400 occasions \\
4 & sometimes failure occurs & 1 failure on 2000 occasions \\
3 & & 1 failure on 15000 occasions \\
2 & Low $(\mathrm{L}):$ prevention is effective so that there & 1 failure on 150000 occasions \\
1 & are relatively few failures & $<1$ failure on 150000 occasions \\
\hline
\end{tabular}

Source: Wang et al. (2009)

risk criteria and alternative controls to be carried out. Based on the value of the risk indicators obtained, a hierarchical structure will be prepared containing the objectives to be achieved, the risk factors that occur, and alternatives control.

Research conducted using a measurement scale in the Fuzzy FMEA method, namely severity, detection, and

occurrence scale in the FMEA fuzzy method. In a simple way, severity is a measurement scale that shows the magnitude of the effect that will be caused as a result of a failure, measurement using severity is indicated by a value of 1 to 10 shown in Table 1 . Measurement using the occurrence scale shows the cause of the risk occurrence and failures during product use, the occurrence

Table 3. Detection Rankings

\begin{tabular}{|c|c|c|}
\hline Rating & Detection & Likelihood of Detection by the Controller \\
\hline 10 & $\begin{array}{l}\text { Absolute Uncertainty } \\
\text { (AU) }\end{array}$ & $\begin{array}{l}\text { There is no controller to detect the cause of failure and the } \\
\text { probability of another failure }\end{array}$ \\
\hline 9 & Very Remote (VR) & $\begin{array}{l}\text { The controller has very little chance to detect the cause of } \\
\text { failure and the probability of another failure }\end{array}$ \\
\hline 8 & Remote (R) & $\begin{array}{l}\text { The controller has little chance to detect the cause of } \\
\text { failure and the probability of another failure }\end{array}$ \\
\hline 7 & Very Low (VL) & $\begin{array}{l}\text { The controller has a very low ability to detect the cause of } \\
\text { the failure and the probability of another failure }\end{array}$ \\
\hline 6 & Low (L) & $\begin{array}{l}\text { The controller has a low ability to detect the cause of the } \\
\text { failure and the probability of another failure }\end{array}$ \\
\hline 5 & Moderate (M) & $\begin{array}{l}\text { The controller has a moderate ability to detect the cause of } \\
\text { the failure and the probability of another failure }\end{array}$ \\
\hline 4 & $\begin{array}{l}\text { Moderately High } \\
(\mathrm{MH})\end{array}$ & $\begin{array}{l}\text { The controller has a moderately high ability to detect the } \\
\text { cause of the failure and the probability of another failure }\end{array}$ \\
\hline 3 & $\operatorname{High}(\mathrm{H})$ & $\begin{array}{l}\text { The controller has a high ability to detect the cause of the } \\
\text { failure and the probability of another failure }\end{array}$ \\
\hline 2 & Very High (VH) & $\begin{array}{l}\text { The controller has a very high ability to detect the cause of } \\
\text { the failure and the probability of another failure }\end{array}$ \\
\hline 1 & Almost Certain (AC) & $\begin{array}{l}\text { The cause of failure and the likelihood of subsequent } \\
\text { failure are almost detected by the controller }\end{array}$ \\
\hline
\end{tabular}

Source: Wang et al. (2009) 
scale is indicated by 10 levels starting from the lowest level of 1 to the highest of 10 which can be seen in Table 2. Meanwhile, detection is a measurement scale that shows the ability to control failure.

Based on the table of severity ranking by Wang et al. (2009), it shows that the value of Fuzzy FMEA obtained indicates an operating system can be done or not along with the effects caused due to the risk of the operating system.

Based on the table of occurrence ranking by Wang et al. (2009), it shows that the resulting Fuzzy FMEA value can be categorized based on the rankings of the probability of risk occurrence so that the failure that may occur from a production system can be determined.

Based on the table of detection ranking by Wang et al. (2009), it shows how big the opportunity to control the failure that might occur. After weighing the Fuzzy FMEA value by the team based on the criteria of severity, occurrence, and detection, the accumulative value of the Fuzzy Risk Priority Number will be obtained which will be used to categorize the priority risks to be controlled. The risk priority categories can be formulated in terms of the weight of risk importance that is presented in Table 4.

Table 4. Weight of Importance Risk Factors

\begin{tabular}{lc}
\hline \multicolumn{1}{c}{ Category } & Fuzzy FMEA Score \\
\hline Very low & $0 ; 0 ; 0,25$ \\
Low & $0 ; 025 ; 0,5$ \\
Medium & 0,$25 ; 0,5 ; 0,75$ \\
High & 0,$5 ; 0,75 ; 1$ \\
Very high & 0,$75 ; 1 ; 1$ \\
\hline
\end{tabular}

The analysis was conducted using the Fuzzy FMEA method on the production of red chili seeds at PT. TAP obtained several risk components that occur in each production process which are presented in Table 5.

Data processing using the AHP method is conducted with the initial stage, namely identifying criteria based on the risk indicators. Further, identifying alternative strategies according to the risks. According to the statement of Atanasova et al. (2014), the AHP method is used to make decisions based on priority measurements from a given scale. Priority determination is based on individual perceptions by considering the relationship of each risk indicator and alternatives in a process. The highest value generated can be

Table 5. Identification of Risk Components in Red Chili Seed Production at PT. TAP, Demak.

\begin{tabular}{|c|c|c|}
\hline No & Production Process & Risk Component \\
\hline 1 & Pre-Planting & $\begin{array}{l}\text { - Seed failure } \\
\text { - Damage to the screen house }\end{array}$ \\
\hline 2 & Planting & $\begin{array}{l}\text { - Lack of seeds } \\
\text { - Many seeds die after planting }\end{array}$ \\
\hline 3 & Maintenance & $\begin{array}{l}\text { - Pest attacks and diseases } \\
\text { - Failure of the pollination process } \\
\text { - Excessive water availability } \\
\text { - Extreme weather conditions } \\
\text { - The chilies feel out }\end{array}$ \\
\hline 4 & Harvesting & $\begin{array}{l}\text { - Harvesting is not on time } \\
\text { - Rotten chilies }\end{array}$ \\
\hline 5 & Post-Harvesting & $\begin{array}{l}\text { - Damage to the seed removing machine } \\
\text { - Suns' intensity is not optimal }\end{array}$ \\
\hline 6 & Storage & $\begin{array}{l}\text { - Moisture content in chili seeds is not according to the } \\
\text { standard } \\
\text { - Storage room temperature is unstable }\end{array}$ \\
\hline
\end{tabular}


considered in the production risk control strategy. The AHP method was chosen to determine the decision making with measures, such as formulating problems and solutions, making a multilevel structure starting from the main goal, making a comparison matrix between the paired elements (variables), followed by determining the priority of the elements obtained from the results of comparison matrix (Saaty, 2008). The control of the production risk of red chili seeds is carried out using the AHP method and weighting based on the criteria and alternative control strategies. There are 6 criteria and control strategies among others are pre-planting, planting, maintenance, harvesting, post-harvesting, and storage.

\section{RESULT AND DISCUSSION}

Research using Fuzzy FMEA (Failure Mode Effect Analysis) was previously used to measure the risk that occurs in the organic rice supply chain at MUTOS Seloliman Trawas Mojokerto. Research conducted by Rohmah et al. (2015) showed the results of the Fuzzy Risk Priority Number (FRPN) value obtained by ranking the risks that occur into several categories coded based on supply chain members (suppliers, manufacturers, distributors, retailers). Fourteen risks are ranked based on the priority of risk based on the resulting FRPN value which is based on the research results on the risk of product return, damage or decline in quality, contamination during the production process, out of stock, presence of competitor products, differences in quality standards, chemical contamination, late supply, delays in the supply process, damage during the production process, damaged equipment during the production process, changes in product demand, damage during storage, and reduced production. Based on the research results, the highest FRPN value obtained is the risk of product return that occurs at the retailer level of 5.54, so it is placed in the first risk priority rank. The second biggest risk is the risk of damage or a decline in quality that occurs to the supplier of 4.99 so that it is in the second risk ranking order, and so on until the lowest risk priority level, namely the risk of reduced production at the manufacturing level with an FRPN value of 2.71 which ranked 14th in risk priority (Rohmah et al., 2015).

Based on the research conducted, there were several risks faced by PT. TAP in each production process of red chili seeds, namely pre-planting, planting, maintenance, harvesting, post-harvesting, and storage. Determination of the highest risk during the red chili seed production process is carried out by identifying and measuring the level of risk based on the FRPN (Fuzzy Risk Priority Number) value reference, the highest value obtained indicates the level of risk that may occur. The results of the analysis of the risk value based on FRPN on the Fuzzy FMEA method are shown in table 6 .

Based on the results obtained from table 5, there are 6 stages of the production process, each of which is at risk. The highest FRPN risk in the pre-planting process stage is the risk of failure in the seedbed of 4.97. Alif (2017) states that the humidity of the seedbed or seedling bed media used must be considered to support the growth of red chili seeds, therefore watering must be done every day. Watering is carried out in the morning or evening with a sufficient volume of water until the soil is wet or adjusted to the growing medium.

The highest FRPN risk in the stages of the growing or planting process is the risk of many red chili seeds dying after transplanting by 5.30. Not all of the seeds that have just been planted will live well and grow into mature plants. The factor that causes the seeds to not survive after planting is the negligence of the labor. The process of transferring seedlings must be done carefully and thoroughly. Furthermore, seeds that are defective due to pests and diseases are still planted into the cultivated land, causing other plants to get pest attacks and diseases and end up with dead plants. Plant embroidery must be done for dead seedlings, but embroidery activities will have an impact on production 
Table 6. Results of FRPN Calculation Risk Components of Red Chili Seed Production at PT. TAP, Demak

\begin{tabular}{lccccc}
\hline \multicolumn{1}{c}{ Pre-planting Risk Components } & Code & S & O & D & FRPN \\
\hline Failure in the nursery & R1 & 1,52 & 1,44 & 2,00 & 4,97 \\
Damage to the screen house & R2 & 1,30 & 1,35 & 1,45 & 4,10 \\
Lack of seeds & R3 & 1,30 & 1,35 & 1,80 & 4,44 \\
Many seeds die after planting & R4 & 1,48 & 1,56 & 2,26 & 5,30 \\
Weather conditions change rapidly & R5 & 1,91 & 1,73 & 2,51 & 6,15 \\
Pest and disease attacks & R6 & 1,87 & 1,70 & 2,47 & 6,03 \\
Failure of the pollination process & R7 & 1,82 & 1,44 & 2,36 & 5,62 \\
Excess water availability & R8 & 1,73 & 1,52 & 2,02 & 5,27 \\
The chilies fell out & $\mathrm{R} 9$ & 1,58 & 1,50 & 1,90 & 4,98 \\
Harvesting is not on time & $\mathrm{R} 10$ & 1,30 & 1,44 & 1,82 & 4,56 \\
Rotten chilies & $\mathrm{R} 11$ & 1,55 & 1,48 & 1,96 & 4,98 \\
Malfunction of the seed removing machine & $\mathrm{R} 12$ & 1,47 & 1,62 & 2,52 & 5,61 \\
The sun's intensity is not maximal & $\mathrm{R} 13$ & 1,66 & 1,35 & 2,49 & 5,51 \\
Unstable temperature in storage room & $\mathrm{R} 14$ & 1,47 & 1,37 & 2,28 & 5,12 \\
The water content of the chili seeds is not up to & $\mathrm{R} 15$ & 1,58 & 1,26 & 2,34 & 5,18 \\
standard & & & & \\
\hline
\end{tabular}

results. According to Prajnanta (2006), embroidery using the same seeds as before can have a negative impact because the seeds used are too old so that the production yield will be less than the seeds that are transplanted on time.

The highest FRPN risk in the maintenance process stage is the risk of weather changes of 6.15 . This risk component is the highest risk component of all identified risk components. Erratic or extreme weather conditions that change a lot day to day from hot and suddenly rain causes red chili plants to be unable to adapt and causes stunted growth of red chili plants. The weather can change erratically from hot, cloudy to rainy weather at any time. Weather conditions can also affect rainfall, high rainfall affects the humidity level of the cultivation environment which results in pest attacks and disease. The use of screen houses on chilies makes the environment even more humid. An environment with high humidity levels can support the growth of pests and plant diseases.

The highest FRPN risk at the stage of the harvesting process is the risk of rotten fruit by 4.98 . One of the causes of rotting fruit that occurs at PT.TAP is fruit fly pests, where fruit flies are insects that like fruits. Fruit flies attack young fruit, almost ripe to ripe fruit. According to Meilin (2014), fruit flies attack chili plants on red chilies ranging from young to ripe ones. Another opinion was stated by Van Sauers-Muller (2005), fruit fly attacks that occurred in red chilies occurred from young to ripe fruit, but attacks were more visible in almost ripe fruits. The fruit fly population is also affected by rainfall, the higher the rainfall, the higher the population of the fruit fly pest population. Therefore, the higher the attack of fruit fly pests, the higher the rotten fruit that occurs in cultivation.

The highest FRPN risk in the postharvesting process stage is the risk of damage to the seed removing machine of 5.61. In general, the use of machines in each company aims to facilitate and optimize work efficiency. However, the use of a machine does not run optimally due to damage. According to Tarigan et al. (2013), the machine is one of the factors that must operate optimally in every production activity. Machines can operate optimally with regular and precise machine maintenance. 
The highest FRPN risk in the storage process stage is the risk of moisture content in chili seeds which is not according to the standard of 5.18. The moisture content of the red chili seeds determined by the company is $7 \%-8 \%$. The problems that occur are caused by the drying process that is not optimal so that the moisture content of the seeds is still high and uneven from one seed to another. According to Syarief and Kumendong (1997), drying is an effort made to reduce the moisture content in the material to a balanced level of moisture content in dry air conditions or until the moisture content is in a good condition and suitable for storage. Production seeds that do not meet the selection standards will not be accepted in the market, so the seeds will not sell and are destroyed, this will cause losses to the company.

The priority risk components must be controlled immediately to reduce and minimize the impact that will be caused. The formulation of control strategy components is made based on priorities obtained from the result of analysis using the AHP method. The following are the results of the strategy measurement. Based on the results of the priority components, a control strategy can be formulated using the AHP method which is presented in Table 7.

Based on the calculations in Figure 1, shows the weight value of the control strategy criteria at each stage of the production process, and alternative strategies to control the production risk of red chili seeds. Risk

Table 7. Risk Control Strategy in the Production Process of Red Chili Seeds

\begin{tabular}{|c|c|c|}
\hline Goal & Criteria & Alternative Control Strategies \\
\hline \multirow{7}{*}{ 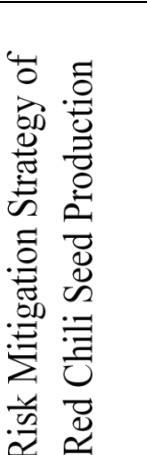 } & Pre-Planting & \multirow{7}{*}{$\begin{array}{l}\text { 1. Doing training \& controlling the workforce } \\
\text { 2. Application of SOPs in the production } \\
\text { process } \\
\text { 3. Production planning and control } \\
\text { 4. Maintain and implement a production } \\
\text { environment } \\
\text { 5. Regular maintenance of production facilities } \\
\text { 6. Equip production facilities }\end{array}$} \\
\hline & Planting & \\
\hline & & \\
\hline & Maintenance & \\
\hline & Harvesting & \\
\hline & Post Harvesting & \\
\hline & Storage & \\
\hline
\end{tabular}

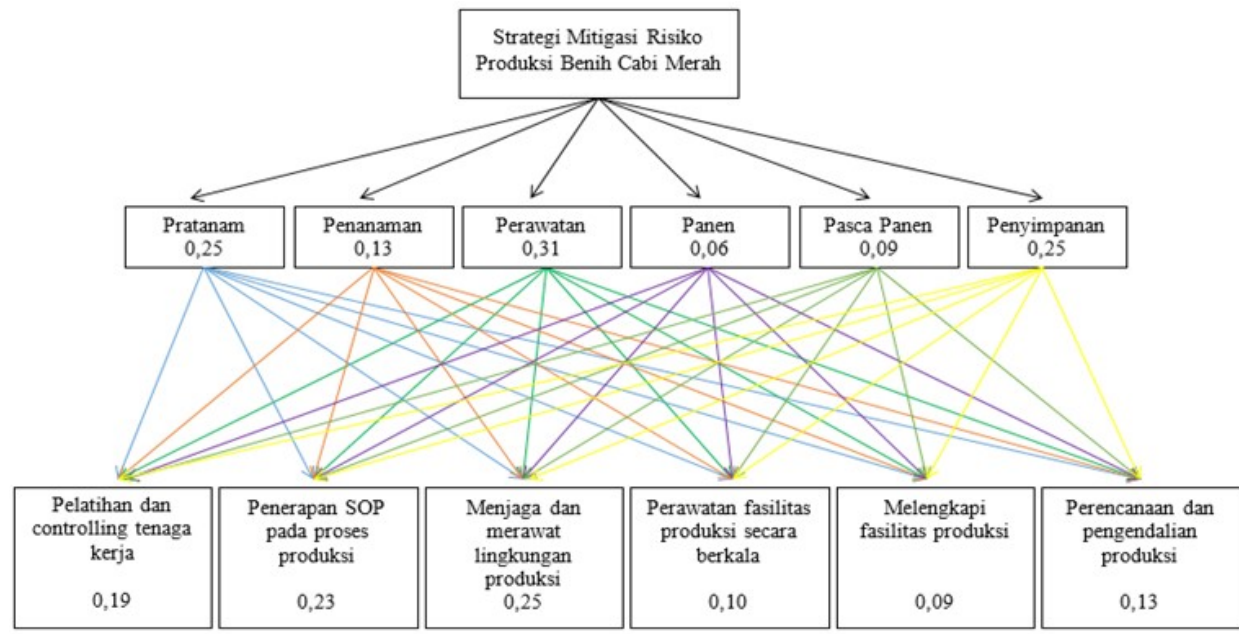

Figure 1. Hierarchical Structure of Risk Control Strategy in Red Chili Seed Production Process at PT. TAP, Demak 
control is carried out based on the results from Table 7 which explains the priority risk components at each stage of the process. The first calculation is conducted using the AHP (Analytical Hierarchy Process) method of risk control strategy criteria used in the study. From the results of the calculation obtained the priority weight values on the criteria at the production process stage and the priority weight values for the entire production process. The control strategy criteria in this study are the stages of the red chili seed production process. Based on Figure 1, the results of the assessment between the criteria for priority risk control strategies are obtained. The main priority criteria are maintenance with a value weight of 0.31 which means that maintenance is the highest priority, this states that this criterion has the highest level of risk that requires fast and precise control, besides this results show that maintenance plays an important role in the production of red chili seeds because maintenance strongly affects the plant development. The main problem in cultivation is dealing with natural factors related to climate and weather. Weather and climate which is unpredictable directly cause a very high risk of damage. Weather risk is declared as the highest priority in the maintenance process because weather changes can affect other risks. Indirectly, weather changes can cause the emergence and increase of pests and diseases.

While the criteria that have the lowest weight value is the harvest process with a value weight of 0.06 , which means that the harvesting criteria have the lowest importance level and have no effect on the yield of red chili seeds. The problem that occurs in harvesting activities is the rotting of red chili caused by fruit fly attacks. According to the Directorate General of Horticulture (2002), pests that have the potential to harm horticultural crops are fruit flies. However, this risk can be controlled if the maintenance process is carried out properly.

The second calculation using AHP is an alternative risk control strategy to obtain priority alternative strategies of production risk. There are 6 alternative risk control strategies formulated. Based on Figure 1, it shows that the weight value of the alternative strategies will be used to minimize the priority of the highest risk component for each criterion. The sequence of priority for risk control strategies for red chili seed production is:

1. Maintain the production environment

Maintaining the production environment is at the highest priority with a weighted value of 0.25 . The production environment at PT. TAP is a cultivation environment, a manufacturing environment used for processing and storing red chili seeds. The strategy for maintaining the environment has been done by PT.TAP using a screen house. Maintaining the environment can be done to reduce damage, namely by making appropriate drainage so that water can flow into the river and the volume of water on the cultivated land is not excessive and flood won't damage the plants. The use of drainage is also accompanied by controlling the environment to ensure that the water conditions are not excessive and inefficient. Temperature and humidity control devices need to be used in the warehouse area to ensure the temperature and humidity levels meet the standards. However, this control is deemed inadequate, therefore it is necessary to improve the storage warehouse environment. Arrangement and grouping of seeds can be done to support the preservation, such as by arranging seeds that have not been or have been packaged on shelves according to the commodity.

2. Implementation of SOPs in the production process

The implementation of SOP (Standard Operating Procedure) in the company is in the second priority of all strategic alternatives with a weight value of 0.23 . According to the US Environmental Protection Agency (2007), SOP is an 
operational guide for the technical implementation of an organization that is managed on a work plan. The use of SOPs is intended to provide information on the correct procedures of work. Also, the use of SOPs is needed to maintain a consistent level of quality and integrity of the output produced. According to Moekijat (2008), SOP is an operational guide covering the steps in carrying out work at each stage, where the work is done and what is done. The application of SOP is more focused on labor in carrying out every task and responsibility. It is expected that SOP can make the workers work according to the regulations. However, the SOP that has been made by the company has not been fully implemented by the workers, and thereby errors and failures in each process still occur.

3. Conduct training and controlling labor Training and controlling the labor are in the third priority strategy that can be used to minimize the risk that occurs in the company with a weight value of 0.19 . Lack of knowledge and skills of workers in the red chili seeds production causes negligence and carelessness and less cautious. Besides, controlling in each stage of production needs to be improved to reduce mistakes made by the labor. Luvitasari and Qanti (2015), training aims to improve quality and quantity, increase compliance and labor cooperation levels to create profitable human resources. Besides, training can be used as a selfquality development of labor. Companies in shaping human resources who are skilled, competent, have good personalities and have sufficient knowledge require labor training to meet the resource needs in the company (Elisa et al., 2014). Job training can be done for both old and new employees to be able to produce qualified labor and meet the needs of the company. Supported by Rivai and Sigala (2009), training is an organized process in shaping one's behavior patterns to achieve organizational goals.
Assembled training with someone's skills and abilities to be able to complete a given job. Training can help the workers in completing work more efficiently and provide useful knowledge for the level of expertise and skills at a job. This is reinforced by the statement of Astaningrum and Endah (2015) that improving the quality of human resources can be done by increasing the standard of education in companies from elementary school level (SD) equal to junior high school level (SMP) to improve thoroughness, cautiousness, and creativity of the labor.

4. Production planning and scheduling

Production process planning is in the fourth strategic priority that can be used to minimize the risk that occurs in the company with a weight value of 0.13 . The scheduling of the production process is carried out before the production period begins, where this activity is important to do as prevention of risks and delays at each stage. According to Surmaini et al. (2011), the adjustment of planting time and pattern in agricultural activities is a strategic effort to reduce the impacts caused by climate change, weather, and rainfall. Scheduling can be used to manage delays at each stage of production. Failures that occur in the seedling and transplanting process require additional time to solve the problem, so adding time to each production is needed as a form of anticipation. Therefore, it is necessary to schedule production properly.

5. Regular maintenance of production facilities

Maintenance of production facilities regularly is in the fifth priority with a weight value of 0.10 . The facilities intended are facilities used at the cultivation stage in the form of screen houses and post-harvest facilities in the form of machines. According to Tarigan et al. (2013), repairs and maintenance of facilities that are only carried out when 
the damage occurs will have an impact on the damage to other components resulting in more severe damage. This will hamper the production process and increase production costs. Routine maintenance will reduce the intensity of damage to production facilities so that the production of red chili seeds will not be hampered. According to Budiyanti et al. (2015), routine and appropriate maintenance aim to prepare machines and other facilities to be used to carry out their duties, so that they can support a smooth production process.

6. Complete production facilities

Completing production facilities is in the lowest priority order of all strategic alternatives formulated with a weight value of 0.09 . The production facility that needs to be equipped is an oven machine that is used for drying red chili seeds. The oven for a dryer at PT.TAP is available, but the machine is only used in the quality control section to dry seeds from other commodities. According to Lee and Lee (2009), oven drying can be used as an alternative solution to reduce the moisture content in seeds. The short-term impact that will be felt is in the form of additional production costs, while the long-term impact is the risk due to high moisture content in the seeds which causes the storage capacity and quality of the seeds to decline due to minimizing moisture content.

\section{CONCLUSION}

The conclusions from this study are based on the results of the analysis and discussion among others are 15 risk components in 6 stages of the production process starting from pre-planting, planting, maintenance, harvesting, post-harvesting, and storage. Measuring risk components using Fuzzy FMEA obtained the highest priority risk component for each variable indicated by the FRPN (Fuzzy Risk Priority Number) value. The highest priority risk component occurs in the maintenance production process caused by extreme weather changes (6.15), then the priority risk occurs in the postharvesting production process, namely damage to the seed removing machine (5.61), in the planting production process, the seedlings die after planting (5.30), in the storage production process there is a risk in the form of water content in chili seeds that do not meet the standards (5.18), in the harvest production process chili rot occurs (4.98), and in the pre-planting production process, failure occurred in the nursery $(4,97)$. Overcoming the risks experienced during the production process of red chili seeds can be done using a production risk control strategy through AHP weighting criteria and alternative control strategies. The highest criteria of weight are in the maintenance process, which is 0.31 so that an alternative control strategy can be done consisting of training and controlling labor, implementing SOPs in the production process, planning and scheduling production, maintaining production environment, maintaining production facilities, and completing production facilities. While the highest weight on the alternative control strategy is maintaining the production environment with a value weight of 0.25 .

Based on the explanation above, there are several suggestions from the research results that can be used by the company and be taken into consideration by PT. TAP to improve and realize risk control strategies that have been formulated based on priorities. This can be done by understanding the probability of the risk occurring at each stage of the production process, arranging a risk priority scale based on alternative controls that must be done so that the highest priority risk components in each production process can be minimized and controlled. Also, to support the timeliness of production, PT. TAP can cooperate with parties who can predict the weather so that the production process of red chili seeds can be done in the proper weather. 


\section{REFERENCES}

Alif, S. M. 2017. Kiat sukses budidaya cabai rawit. Yogyakarta. Biogenesis.

Astaningrum, J. A., and E. Djuwendah. 2015. Analisis risiko usahatani bunga krisan potong (Chrysanthenum indicum L) (Studi kasus di PT Alam Indah Bunga Nusantara). PASPALUM 3(1): 1-8.

Atanasova, T. P., M. Lapevski, and R. Timovski. 2014. Analytical Hierarchical Process (AHP) method application in the process of selection and evaluation. International Scientific Conference UNITECH: 373-380.

Budiyanti, V. E., N. W. Setyanto, and A. Rahman. 2015. Perencanaan jadwal perawatan preventif berbasis keandalan untuk meningkatkan availability mesin kertas (Studi Kasus: PT. Kertas Leces (Persero). Jurnal Rekayasa dan Manajemen Sistem Industri 3(1): 1-10.

Creswell, J. W. 2010. Research design: pendekatan kualitatif, kuantitatif, dan mixed. Yogyakarta. PT. Pustaka Pelajar.

Direktorat Jendral Bina Produksi Hortikultura. 2002. Pedoman pengendalian lalat buah. Jakarta. Direktorat Perlindungan Hortikultura.

Elisa, M. R. M. Efendi, and N. I. Sari. 2014. Peranan pelatihan dalam peningkatan kinerja karyawan: studi kasus bagian operasional PT PLN (PERSERO) Pembangkitan Sumatera Selatan Bagian Selatan. Jurnal Orasi Bisnis Edisi 12: 92-106.

Environmental Protection Agency US. 2007. Guidance for Preparing Standard Operating Procedures (SOPs). Office of Environmental Information, Washington, DC 20460. EPA/600/B07/001.

Iturrioz, R. 2009. Agricultural Insurance (English). Primer Series on Insurance:
Issue No. 12. Washington, DC. World Bank.

Lee, S. W., and J. H. Lee 2009. Effects of oven drying, roasting, and explosive puffing process on isoflavone distributions in soybeans. Food Chemistry 112(2): 316-320.

Luvitasari, D., and S. R. Qanti. 2015. Analisis risiko produksi bunga mawar potong (Rosa hybrida) (Studi kasus di Rosalia Flowers, Desa Cihideung, Kecamatan Parompong, Kabupaten Bandung Barat). Prosiding. Seminar Nasional Pembangunan Inklusif di Sektor Pertanian II: 155-162.

Meilin, A. 2014. Hama dan penyakit pada tanaman cabai serta pengendaliannya. Jambi. Balai Pengkajian Teknologi Pertanian Jambi.

Moekijat. 2008. Administrasi perkantoran. Bandung. Mandar Maju.

Prajnanta, F. 2006. Agribisnis cabai hibrida (XIII). Jakarta. Penebar Swadaya.

Rabbi, M. F. 2018. Assessment of Fuzzy Falure Mode and Effect Analysis (FMEA) for reach stacker crane (RST): A Case Study. International Journal of Research in Industrial Engineering 7(3): 336-348.

Risqiyah, I. A., and I. Santoso. 2015. Risiko rantai pasok agroindustri salak menggukanan fuzzy FMEA. Jurnal Manajemen \& Agribisnis 14(1): 1-11.

Rivai, V., and Sagala. 2009. Manajemen sumber daya manusia untuk perusahaan. Jakarta. PT. Rajagrafindo Persada.

Rohmah, D. U. M., W. A. P. Dania, and I. A. Dewi. 2015. Risk measurement of supply chain organic rice product using fuzzy failure mode effect analysis in MUTOS Seloliman Trawas Mojokerto. The 2014 International Conference on Agro-industry (ICoA): Competitive and Sustainable Agro- 
industry for Human Welfare. Expert Systems with Applications Agriculture and Agricultural Science 36(2): 1195-1207.

Procedia 3: 108-113.

Saaty, T. L. 2008. Decision making with the analytic hierarchy process. International Journal of Services Sciences 1(1): 83-98.

Sharma, R. K., and P. Sharma. 2010. Methodology and theory: system failure behavior and maintenance decision making using, RCA, FMEA, and FM. Journal of Quality in Maintenance Engineering 16(1): 6488.

Singla, S., and M. Sagar. 2012. Integrated risk management in agriculture: an inductive research. The Journal of Risk Finance 13(3): 199-214.

Surmaini, E., E. Runtunuwu, and I. Las. 2011. Upaya sektor pertanian dalam menghadapi perubahan iklim. Jurnal Litbang Pertanian 30(1): 1-7.

Syarief, R., and J. Kumendong. 1997. Penanganan panen dan pasca panen jagung dalam rangka meningkatkan mutu jagung untuk industri ekspor. Temu Teknis BP BIMAS Dep. Pertanian. Jakarta.

Tarigan, P., E. Ginting, and I. Siregar. 2013. Perawatan mesin secara preventive maintenance dengan modularity design pada PT.RXZ. E-Jurnal Teknik 3(3): 35-39.

Van Sauers-Muller, A. 2005. Host plants of the Carambola Fruit Fly, Bactrocera carambolae drew \& Hancock (Diptera: Tephritidae), in Suriname, South America. Neotropical Entomology 34(2): 203-214.

Wang, Y. M., K. S. Chin, G. K. K. Poon, and J. B. Yang. 2009. Risk evaluation in failure mode and effects analysis using fuzzy weighted geometric mean. 